Vitenskapelig publikasjon

\title{
Voldsutsatte minoritetskvinners rettssikkerhet i Norge
}

Fredrikke Fjellberg Moldenas

Fredrikke Fjellberg Moldenæs har master i rettsvitenskap fra Det juridiske fakultet, UiT Norges arktiske universitet. Artikkelen er basert på masteroppgaven som ble levert våren 2019.

\section{Fredrikke1995@live.no}

\section{Sammendrag}

Utlending som søker om oppholdstillatelse i Norge på bakgrunn av familiegjenforening og/eller familieetablering med ektefelle eller samboer, må etter dagens regelverk bo sammen med ektefelle eller samboer i tre år for å få permanent oppholdstillatelse, jf. utlendingsloven $\S$ 62 første ledd, jf. $\S 40$ tredje ledd og $\S 41$ første ledd. ${ }^{1}$ Dersom samlivet opphører tidligere, må utlending som hovedregel forlate riket. En mulig konsekvens av treårskravet er dermed at utlending blir i forholdet av frykt for å bli sendt ut av landet. Denne artikkelen vil ta for seg treårskravet, og kravets negative konsekvenser for minoritetskvinner som utsettes for vold av sin samboer eller ektefelle. Et unntak fra hovedregelen er utlendingsloven $§ 53$ første ledd bokstav b som gir rett til oppholdstillatelse på selvstendig grunnlag på bakgrunn av mishandling i samlivsforholdet. Spørsmålet er om unntaksbestemmelsen evner å begrense de negative konsekvensene av treårskravet.

\section{Nøkkelord}

mishandling, minoritetskvinner, oppholdstillatelse, menneskerettigheter, rettssikkerhet, retten til familieliv

\section{Innledning}

Jeg vil i denne artikkelen først peke på noen negative konsekvenser av treårsregelen for voldsutsatte minoritetskvinner, et begrep som i denne artikkelen brukes om kvinner med innvandrer- og flyktningbakgrunn. ${ }^{2}$ Jeg fokuserer på kvinner fordi de er overrepresentert på

\footnotetext{
${ }^{1}$ Lov 15. mai 2008 nr. 35 om utlendingers adgang til riket og deres opphold her (heretter utlendingsloven). Med utlending siktes det $\mathrm{i}$ artikkelen og i loven til enhver som ikke er norsk statsborger, jf. utlendingsloven $\S 5$ første ledd.

${ }^{2}$ Se bl.a. Ot.prp. nr. 75 (2006-2007) Om lov om utlendingers adgang til riket og deres opphold her (utlendingsloven) kapittel 9.8.2.1. Begrepet «minoritetskvinner» tillegges samme betydning i NOU 2003: 31
} 
søkersiden. ${ }^{3}$ For å besvare spørsmålet om utlendingsloven $\S 53$ første ledd bokstav b evner å begrense de negative konsekvensene av treårskravet, vil jeg deretter fastlegge innholdet av bestemmelsen og vurdere om praktiseringen av unntaksbestemmelsen på forvaltningsnivå oppfyller de kravene som stilles i lov, forarbeider og rettspraksis. Tolkes bestemmelsen i praksis strengere enn det rettstilstanden tilsier at den skal ${ }^{4}$ Underveis i vurderingen $\emptyset$ nsker jeg å belyse noen av de vurderingsmomenter i forarbeidene som kan være med på å svekke rettssikkerheten til voldsutsatte minoritetskvinner. ${ }^{5}$

To av vilkårene i utlendingsloven $§ 53$ første ledd bokstav b er mer skjønnsmessige enn de $\emptyset$ vrige. Det er kravet til mishandling og «grunn til å anta». Jeg vil i det følgende avgrense mot utdyping av vilkåret om «grunn til å anta» og heller gå nærmere inn på kravet til mishandling. Årsaken er at jeg anser kravet til mishandling å være det vilkåret som det strides mest om i praksis. Det betyr at jeg i denne artikkelen ikke vil behandle beviskravet i utlendingsloven $\S$ 53 første ledd bokstav b.

Samtidig er det av betydning for å forstå «mishandlingsbestemmelsen» at det innledningsvis nevnes kort at vilkår om «grunn til å anta» betyr at beviskravet er lavt. Det vil si at søkerens fremstilling skal legges til grunn dersom søkeren gir en troverdig forklaring. ${ }^{6}$ Strafferettens strenge beviskrav gjelder ikke innenfor sivilretten og forvaltningsretten.

Hva som ligger i mishandlingsbegrepet og hvordan begrepet tolkes etter andre lovbestemmelser, kan gi en indikasjon på hvilke handlinger som omfattes av begrepet. Både utlendingslovens bestemmelse om oppholdstillatelse på selvstendig grunnlag og straffelovens bestemmelse om mishandling i nære relasjoner oppstiller et vilkår om mishandling, jf. straffeloven $\S 282$ første ledd. ${ }^{7}$ Derfor vil jeg i min redegjørelse for mishandlingsbegrepet i utlendingsloven også vise til straffelovens mishandlingsbegrep.

Retten til et liv uten vold. Menns vold mot kvinner i nære relasjoner. Utredning avgitt fra et utvalg oppnevnt ved kongelig resolusjon 29. august 2001. Avgitt til Justis- og politidepartementet 4. desember 2003, s. 54.

${ }^{3}$ UDI statistikk, «Familieinnvandringstillatelser etter søkerens statsborgerskap, aldersgruppe og kjønn», 2019 https://www.udi.no/statistikk-og-analyse/statistikk/familieinnvandringstillatelser-etter-sokerens-statsborgskapaldersgruppe-og-kjonn-2019/ (sist besøkt 15.2.2020).

${ }^{4}$ Viser til kritikk av praktiseringen som støtte for at spørsmålet stilles. Se bl.a. Prop. 68 L (2017-2018) Endringer i utlendingsloven mv. (utvisning på grunnlag av eksklusjon fra flyktningstatus mv.), kapittel 3.3.4.2.

${ }^{5}$ Med begrepet «rettssikkerhet» siktes det i denne artikkelen mest til materiell rettssikkerhet, men også prosessuell rettssikkerhet som beskrevet i Jan Fridthjof Bernt og Ørnulf Rasmussen, Frihagens forvaltningsrett, bind 1, 2.utgave 5.opplag, Bergen 2017, s. 46-51.

${ }^{6}$ Ot.prp. nr. 75 (2006-2007) s. 233.

${ }^{7}$ Lov 20. mai 2005 nr. 28 om straff (heretter straffeloven). 


\section{Treårskravets negative konsekvenser}

Formålet med familieinnvandring er at mennesker som er i nær familie, skal få bo sammen. ${ }^{8}$ Det er på bakgrunn av dette formålet at utlendinger får opphold i Norge. Lovens krav til tre års botid sammen, og de $\varnothing$ vrige vilkår som oppstilles, er i så måte både rimelige og gjennomførbare. Ved et vanlig familieliv, vil vilkårene i utgangspunktet ikke være vanskelig å oppfylle. Det stiller seg annerledes hvis samlivsforholdet er preget av vold. Treårskravet vil da kunne komme i konflikt med retten til et liv uten vold. ${ }^{9}$

For det første kan treårskravet innebære at voldutsatte minoritetskvinner ikke kommer seg ut av et mishandlingsforhold. En kvinne med selvstendig oppholdstillatelse vil kunne flytte ut, ta avstand til voldsut $\varnothing v e r, o g$ fremdeles få oppholde seg i riket. En person som oppholder seg i Norge på grunn av familieinnvandring, må i utgangspunktet forlate landet. Flere kvinner gir uttrykk for at det er svært vanskelig å måtte dra tilbake til hjemlandet som skilt kvinne. ${ }^{10} \mathrm{Av}$ frykt for å bli sendt tilbake tør kvinnene dermed ikke bryte ut av forholdet før det har gått tre år. ${ }^{11}$

For det andre kan det stilles spørsmål ved om treårskravet medvirker til å skape en ubalanse mellom kvinne og mann. Vold har blant annet grunnlag i maktforskjeller mellom kjønnene. ${ }^{12}$ Ofte vil ektemannen ha større nettverk enn kvinnen i Norge, kunne språket bedre og styre over de økonomiske ressursene. ${ }^{13}$ Gjennom isolasjon kan han begrense kvinnens tilgang på informasjon. ${ }^{14}$ Det vil si at han har kontrollen. Noen ektemenn gjør sitt beste for å integrere

\footnotetext{
${ }^{8}$ Se bl.a. Convention for the Protection of Human Rights and Fundamental Freedoms, 4 November 1950 (heretter EMK) artikkel 8 nr. 1, og lov 17. mai 1814 Kongeriket Norges Grunnlov (Grunnloven) § 102 første ledd.

${ }^{9}$ Vold mot kvinner er et brudd på menneskerettighetene, jf. Council of Europe Convention on preventing and combating violence against women and domestic violence, 5 November 2011 (Istanbul-konvensjonen) artikkel 3 bokstav a. Se også EMDs dom 12. juni 2008 Bevacqua og S mot Bulgaria avsnitt 77-84.

${ }^{10}$ Se bl.a. NOU 2003: 31 Retten til et liv uten vold, s. 161.

${ }^{11}$ Mira ressurssenter for kvinner med minoritetsbakgrunn, «MiRASenterets rapport om forebygging av vold i minoritetsperspektiv», Oslo 2015 (heretter MiRA-Senteret) (s. 28).

${ }^{12}$ Se bl.a. NOU 2003: 31 Retten til et liv uten vold, s. 28, og MiRA-Senteret (s. 16).

${ }^{13}$ Guri Tyldum og Marianne Tveit, «Someone who cares. A study of vulnerability and risk in marriage migration from Russia and Thailand to Norway», Fafo-rapport, Oslo 2008 (s. 8).

${ }^{14}$ Likestillings- og diskrimineringsombudet, «Høringssvar - endringer i utlendingsloven og utlendingsforskriften - hevet botidskrav for permanent oppholdstillatelse mv. - endringer i statsborgerloven», 2015 (kapittel 5, «Svakheter ved implementeringen av unntaksbestemmelsen») https://www.regjeringen.no/contentassets/a7935befc95d40c88e5d25e98db5f967/ldo.pdf?uid=Likestillings_og_diskrimineringsombud.pdf (sist besøkt 2.4.2019).
} 
partneren i det norske samfunn slik at kvinnen kan bli selvstendig. ${ }^{15}$ Andre ser en mulighet til å forsterke kvinnens avhengighet. ${ }^{16}$

I HR-2019-621-A var voldsbruken i stor grad knyttet til det skjeve maktforholdet mellom kvinne og mann grunnet treårskravet. Saken gjelder mishandling i nære relasjoner etter straffeloven $1902 \S 219 .{ }^{17}$ Denne bestemmelsen er videreført i straffeloven $2005 \S 282$ uten annen realitetsendring enn at strafferammen er hevet. ${ }^{18}$ Over en periode på rundt fire måneder hadde mannen i beruset tilstand nærmest daglig vært aggressiv mot sin 26 år yngre utenlandske ektefelle. ${ }^{19}$ Blant annet vekket han henne flere gang hver natt, ba henne stå opp, pakke sakene sine og bestille flybillett tilbake til et land i Asia. Ved flere anledninger pakket kvinnen kofferten for at tiltalte skulle slutte å mase på henne. Mannen fikk kvinnen til å tro at politiet ville sende henne tilbake om de ble gjort kjent med at han ikke var snill med henne. Kvinnen var «svært engstelig» for at mannen skulle trekke seg som referanse for henne, slik han gjentatte ganger truet med. ${ }^{20}$

Flere av UNEs offentliggjorte vedtak viser at referanseperson ofte fremsetter trusler om tilbakesendelse. ${ }^{21}$ En rapport fra Fafo peker på at flere utenlandske kvinner lever med vedvarende trusler om skilsmisse. ${ }^{22}$ For å sikre at ekteskapet varer i tre år, tilpasser de seg ektemannens $\emptyset$ nsker i langt større grad enn de normalt ville gjort. Flere kvinner forteller at de har blitt kastet ut av huset på grunn av en krangel. Kvinner forteller at de har blitt møtt med forventninger om å leve opp til utdaterte kjønnsrollemønster for å forbli gift. ${ }^{23}$

Statistikk viser at mange av kvinnene som kommer til Norge, er fra andre deler av verden, med helt andre normer og regler. ${ }^{24}$ Flere av disse kvinnene vet svært lite om sine rettigheter. ${ }^{25}$ UDI informerer om treårskravets unntaksbestemmelse på sine nettsider. ${ }^{26}$ Krisesentrene vil

\footnotetext{
${ }^{15}$ Guri Tyldum og Marianne Tveit (s. 9).

${ }^{16}$ Guri Tyldum og Marianne Tveit (s. 10).

${ }^{17}$ Lov 22. mai 1902 nr. 10 Almindelig borgerlig Straffelov (straffeloven). Opphevet.

${ }^{18}$ HR-2019-621-A (avsnitt 14, som viser til Ot.prp. nr. 22 (2008-2009) side 433).

${ }^{19}$ HR-2019-621-A (avsnitt 11 og 32).

${ }^{20}$ HR-2019-621-A (avsnitt 11 og 20).

${ }^{21}$ Se bl.a. vedtak N1838300214, 2017 - https://www.une.no/kildesamling/praksisbaselandingsside/2017/juni/n1838300214/ (sist besøkt 15.2.2020).

${ }^{22}$ Se fotnote 15.

${ }^{23}$ Se fotnote 13 .

${ }^{24}$ Se fotnote 3.

${ }^{25}$ Se fotnote 15 .

${ }^{26}$ UDI, «Oppholdstillatelse for deg som har blitt mishandlet»-https://www.udi.no/skal-soke/oppholdstillatelsefor-de-som-har-blitt-mishandlet/ ( sist besøkt 9.4.2019).
} 
også kunne gi informasjon til dem som oppsøker disse. Juridisk rådgivning for kvinner (heretter JURK) får likevel mange henvendelser fra kvinner som ikke kjenner til unntaksregelen fra treårskravet. ${ }^{27}$ De mener informasjon om bestemmelsen ikke når frem. Justis- og beredskapsdepartementet erkjenner at det kan være en utfordring å nå ut til de grupper som ikke kommer i kontakt med ovennevnte instanser. ${ }^{28}$

Videre viser statistikken at behovet for tolk under opphold på krisesenter var fremtredende for beboere med innvandrerbakgrunn. ${ }^{29}$ Det kan dermed legges til grunn at flere av kvinnene heller ikke forstår eller kan gjøre seg forstått på norsk. Språk vil kunne begrense kvinnens tilgang på informasjon og kommunikasjon med omverdenen. Det vil være et problem i møte med det norske samfunn, politi, helsetjenester og andre hjelpeinstanser. Språk kan også skape problemer mellom ektefellene. I de tilfeller hvor en norsk mann gifter seg med en utenlandsk kvinne, vil de ofte være avhengig av tolk eller engelsk for å kunne kommunisere med hverandre. ${ }^{30}$ En slik situasjon kan føre til misforståelser og manglende kommunikasjon om hvilke forventninger paret har til ekteskapet. ${ }^{31}$

Manglende informasjon om rettigheter, $\varnothing$ konomisk avhengighet og språkproblemer er ikke direkte følger av treårskravet. Samtidig vil treårskavet kunne skape et avhengighetsforhold til referanseperson, som forsterkes av at kvinnene ofte ikke har tilstrekkelig kunnskap om egne rettigheter, er økonomisk avhengig av ektemannen, og ikke forstår eller kan gjøre seg forstått på norsk.

Med bakgrunn i de foran nevnte momenter kan det konkluderes med at treårskravet er med på å svekke minoritetskvinners rettssikkerhet i Norge. Oppsummert kan det argumenteres for at

\footnotetext{
${ }^{27}$ JURK, «Høring - hevet botidskrav for permanent oppholdstillatelse», 2015 (s. 4) https://www.regjeringen.no/no/dokumenter/horing--endringer-i-utlendingsloven-og-utlendingsforskriften--hevetbotidskrav-for-permanent-oppholdstillatelse-mv.--endringer-i-statsborgerloven/id2403994/?uid=ef065f71-959e44d8-b08e-867d174ba571 (sist besøkt 2.4.2019).

${ }^{28}$ Justis- og beredskapsdepartementet, «Høringsnotat - endringer i utlendingsloven og utlendingsforskriften hevet botidskrav for permanent oppholdstillatelse mv. - endringer i statsborgerloven», 2015 (s. 11) https://www.regjeringen.no/contentassets/461dabc103d34c52a5b9cf4f1f8f81d9/horingsnotat---7056.pdf (sist besøkt 2.4.2019).

${ }^{29}$ Bufdir statistikk, «Beboere med innvandrerbakgrunn», 2018 -

https://www.bufdir.no/Statistikk_og_analyse/Vold_og_overgrep_tall_og_statistikk/Krisesentertilbudet_i_norske _kommuner/Om_beboerne/\#heading46775 (sist besøkt 14.10.2019).

${ }^{30}$ Se fotnote 13 .

${ }^{31}$ Se fotnote 13.
} 
kravet til tre års botid kun er forsvarlig dersom unntaksbestemmelsen for mishandlingstilfeller faktisk fungerer.

\section{Mishandlingsbestemmelsenes innhold}

Retten til oppholdstillatelse på selvstendig grunnlag er regulert i utlendingsloven $\S 53$ første ledd bokstav b. Bestemmelsen lyder som følger:

«En utlending som har oppholdstillatelse etter $\S \S 40$ eller 41, skal etter søknad gis ny oppholdstillatelse på selvstendig grunnlag dersom [...] b) samlivet er opphørt, og det er grunn til å anta at utlendingen eller eventuelle barn har blitt mishandlet $\mathrm{i}$ samlivsforholdet eller av andre medlemmer av samme husstand, eller av svigerfamilie.»

Hvilke handlinger som omfattes av begrepet «mishandling», kan ikke leses ut av bestemmelsens ordlyd. Sammensetningen av «mis» og «handling» tilsier likevel at det er tale om en samlebetegnelse for ulike handlinger av negativ karakter.

I straffeloven er mishandling i nære relasjoner sett i sammenheng med trusler, tvang, frihetsberøvelse, vold eller andre krenkelser, jf. ordlyden i straffeloven $§ 282$ første ledd. Mishandling utøvet av nåværende eller tidligere ektefelle eller samboer anses som mishandling i nære relasjoner, jf. straffeloven $§ 282$ første ledd bokstav a. Mishandlingen må være alvorlig eller gjentatt, jf. straffeloven $§ 282$ første ledd.

Ved behandling av ny utlendingslov ble det sett på hvilken alvorlighetsgrad og hvilket omfang de aktuelle krenkelsene må ha for å anses som mishandling i utlendingslovens forstand. Mishandlingsbegrepet ble ifølge forarbeidene videreført for å unngå at terskelen justeres for høyt i praksis. ${ }^{32}$ Forarbeidene viser til rundskriv UDI 02-117. Departementet mente den forståelsen av mishandling som ble lagt til grunn for skjønnsvurderingen i UDI, lå på et riktig nivå, og sluttet seg til utvalgets anbefaling om å videreføre dagjeldende praksis. ${ }^{33}$ Forvaltnings- og domstolspraksis fra før 2010 vil dermed være av betydning ved lovtolkningen.

\footnotetext{
32 Ot.prp. nr. 75 (2006-2007) s. 231.

${ }^{33}$ Ot.prp. nr. 75 (2006-2007) s. 234. Någjeldende rundskriv gir uttrykk for de samme vurderingsmomenter, se UDIRS-2010-9.
} 
I det følgende vises det til den delen av rundskrivet som nevnes i forarbeidene. Etter rundskrivet vil hva som betegnes som mishandling, bero på en helhetsvurdering, og en rekke momenter er av betydning. ${ }^{34}$ Mishandling både av fysisk og psykisk art omfattes, men hendelsene må ha ført til redusert livskvalitet for søkeren. Det er videre et krav om fysisk eller psykisk skade, eller en kombinasjon av begge. Dersom en handling gjentas over tid, kan handlingen kvalifisere til mishandling, selv om enkelthendelsen i seg selv ikke anses som mishandling. ${ }^{35}$ Misnøye i forholdet, uoverensstemmelser eller ulike oppfatninger av roller grunnet kulturforskjeller er ikke i seg selv nok for å konstatere mishandling. ${ }^{36}$

Uttalelser i forarbeidene til utlendingsloven tyder på at terskelen for å konstatere mishandling etter utlendingsloven er lav. Videre gir forarbeidene uttrykk for et nokså vidt spillerom for dem som treffer avgjørelser i den konkrete saken. Vurderingsmomentene indikerer at lovgiver $\emptyset$ nsker at forvaltningen skal tillegges stor skjønnsmyndighet. Særlig vurderingen av redusert livskvalitet kan tenkes å gi grunnlag for et stort tolkningsrom hos den enkelte saksbehandler.

Psykisk mishandling omfattes også av straffelovens mishandlingsbestemmelse. ${ }^{37}$ Det vil si at psykiske krenkelser som i seg selv ikke er straffbare, omfattes dersom de skjer vedvarende og gjentakende i et visst omfang. ${ }^{38}$ Det skal likevel mer til for å konstatere mishandling dersom krenkelsene er av utelukkende psykisk art, enn om krenkelsene også er fysiske. ${ }^{39} \mathrm{Av}$ straffelovens forarbeider fremgår det også at blant annet seksuelle krenkelser kan omfattes av alternativet andre krenkelser. ${ }^{40}$

På noen områder skiller forarbeidene til utlendingsloven $\S 53$ første ledd bokstav b seg fra forarbeidene til straffeloven $\S 282$. Straffelovens forarbeider gir uttrykk for at fokuset er rettet mot voldshandlingene. Det er gjerningspersonens voldsutøvelse som er gjenstand for

\footnotetext{
${ }^{34}$ Herunder: « ... de beskrevne hendelsene, alvorlighetsgraden, under hvilke omstendigheter mishandlingen fant sted, om de er en del av et handlingsmønster eller om det dreier seg om en enkeltstående episode», jf. Ot.prp. nr. 75 (2006-2007) s. 230.

35 Ot.prp. nr. 75 (2006-2007) s. 230.

${ }^{36}$ Utvalget presiserer i forarbeidene at «det ikke er grunnlag for å senke terskelen så lavt at bestemmelsen får anvendelse $\mathrm{i}$ alle tilfeller hvor noen har havnet $\mathrm{i}$ et ulykksalig samliv med en lite hensynsfull eller kynisk samlivspartner», jf. Ot.prp. nr. 75 (2006-2007) s. 230.

${ }^{37}$ Prop. 66 S (2016-2017) Samtykke til ratifikasjon av Europarådets konvensjon av 11. mai $2011 \mathrm{om}$ forebygging og bekjempelse av vold mot kvinner og vold i nære relasjoner, s. 18.

${ }^{38}$ Ot.prp. nr. 113 (2004-2005) Om lov om oppheving av løsgjengerloven og om endringer i straffeloven mv. (eget straffebud mot vold i nære relasjoner), s. 36-37 og mindretallet i HR-2019-621-A (avsnitt 31).

${ }^{39}$ Se bl.a. Rt. 2013 s. 879 (avsnitt 31).

${ }^{40}$ Ot.prp. nr. 113 (2004-2005) s. 45.
} 
vurdering, og ikke hvordan offeret har reagert på voldsbruken. Ifølge straffelovens forarbeider er det ikke krav om at krenkelsen må ha ført til et skaderesultat på offerets legeme eller sjel. ${ }^{41}$ Det oppstilles - så vidt jeg kan se - heller ikke et krav om at mishandlingen må ha ført til redusert livskvalitet for offer.

\section{Terskelen for mishandling i rettspraksis}

Det er lite rettspraksis vedrørende oppholdstillatelse på selvstendig grunnlag på grunn av mishandling. Det er ingen dommer fra Høyesterett, og kun én sak er behandlet av domstolen etter ikrafttredelsen av ny utlendingslov i 2010: LB-2016-116118-2 (Borgarting lagmannsrett). Til forrige utlendingslov finner jeg tre dommer fra Oslo tingrett som behandler oppholdstillatelse på selvstendig grunnlag på grunn av mishandling. ${ }^{42}$ Det foreligger med andre ord få holdepunkter for å kunne si noe konkret om hvor terskelen for mishandling legges i rettspraksis.

Jeg vil i det følgende vise til de tre siste dommer som foreligger etter mishandlingsbestemmelsen, fordi hvor terskelen for mishandling legges i praksis, kommer frem i disse dommene. Høyesterett vurderer i tidligere nevnte HR-2019-621-A (dissens 3-2) hvor terskelen for mishandling i nære relasjoner etter straffeloven går, og jeg vil også trekke inn denne avgjørelsen i min vurdering. Videre viser jeg til offentliggjort forvaltningspraksis på området. Da de fleste avgjørelser blir truffet på forvaltningsnivå, er det avgjørende for kvinnenes rettssikkerhet at forvaltningen legger til grunn lovgivers forståelse av mishandlingsbegrepet.

Høyesterett ga i HR-2019-621-A uttrykk for at truslene som fremsettes og den øvrige voldsbruken må ses i sammenheng med hvor hardt de rammer den fornærmede. ${ }^{43}$ Flertallet mente at kroppskrenkelser av mindre alvorlig grad, samt aggressiv og krenkende adferd over en periode på fire måneder, ikke kvalifiserte til mishandling etter straffeloven. $^{44}$

Voldsutøvelsen ble imidlertid av Høyesteretts flertall ansett for å være et grensetilfelle for mishandling, til tross for at hendelsene isolert sett ikke ble ansett for å være særlig

\footnotetext{
${ }^{41}$ Ot.prp. nr. 113 (2004-2005) s. 46.

42 TOSLO-2006-15372 (Oslo tingrett), TOSLO-2009-76156 (Oslo tingrett) og RG-1997-345 (58-97) (Oslo byrett).

${ }^{43}$ HR-2019-621-A (avsnitt 21). Redegjørelse av sakens faktum fremgår under punkt om negative konsekvenser.

${ }^{44}$ Se fotnote 43 .
} 
alvorlige. ${ }^{45}$ Årsaken var tiltaltes nedrige og rammende utnytting av fornærmedes sårbarhet. ${ }^{46}$ Høyesterett mente den utenlandske kvinnen ble rammet spesielt hardt av ektemannens trusler om å frata henne jobben og sende henne ut av landet. Hun hadde nylig kommet til Norge fra en annen kultur, hun hadde et begrenset nettverk og manglende innsikt i norsk språk og norske forhold. Mindretallet mente kravet til mishandling etter straffeloven var oppfylt. ${ }^{47}$

Det kan argumenteres for at tilsvarende handlinger som nevnt i høyesterettsdommen bør anses som mishandling etter utlendingsloven. Mishandlingsbestemmelsen i utlendingsloven er ikke en sanksjonsregel, men en rettighetsbestemmelse for søker. Selv om det kan virke stigmatiserende for referanseperson at søker får opphold på bakgrunn av mishandling, vil mishandling som faller inn under utlendingsloven, ikke nødvendigvis føre til straff for referanseperson. ${ }^{48}$

Som støtte for mitt syn trekker jeg frem at Borgarting lagmannsrett har uttalt i LB-2016116118-2 at terskelen for å konstatere mishandling etter utlendingsloven er lavere enn for mishandlingsbegrepet i straffelovens paragraf om mishandling i nære relasjoner. ${ }^{49}$

Lagmannsrettdommen omhandler en kvinne som i Ghana i 2006 giftet seg med en person som bodde i Norge, og ble innvilget midlertidig oppholds- og arbeidstillatelse på bakgrunn av familieinnvandring. I 2009 søkte kvinnen om oppholdstillatelse på selvstendig grunnlag med den begrunnelse at hun var blitt utsatt for vold av ektemannen. Lagmannsretten mente at mishandlingsvilkåret ikke var oppfylt. Det var ikke tilstrekkelig sannsynliggjort at kvinnens livskvalitet var redusert på grunn av krenkelsene.

I TOSLO-2006-15372 (Oslo tingrett) anså retten handlingene for å ligge innenfor kjerneområdet til mishandlingsbegrepet, og at kravet til mishandling etter utlendingsforskriften var oppfylt. ${ }^{50}$ Staten ved UNE (heretter staten) mente verken kvinnen eller sønnen var blitt mishandlet i utlendingsforskriftens forstand. ${ }^{51}$ Den russiske kvinnen anførte at ektefellen var kontrollerende, humørsyk og hadde voldelig adferd. ${ }^{52}$ Kvinnen og

\footnotetext{
${ }^{45}$ HR-2019-621-A (avsnitt 19).

${ }^{46}$ Se fotnote 43.

${ }^{47}$ HR-2019-621-A (avsnitt 35).

${ }^{48}$ Ot.prp. nr. 75 (2006-2007) s. 234.

${ }^{49}$ LB-2016-116118-2 (Borgarting lagmannsrett).

${ }^{50}$ TOSLO-2006-15372 (Oslo tingrett).

${ }^{51}$ Se fotnote 50 .

${ }^{52} \mathrm{Se}$ fotnote 50 .
} 
hennes sønn ble kastet ut av huset, fikk ikke bestemme hva de skulle spise, barnetrygden gikk inn på ektefellens konto, og kvinnen fikk svært lite penger til mat. Sønnen fikk strengere restriksjoner dersom kvinnen ikke ønsket å ha samleie med ektefellen. Hendelsene ble fra statens side betegnet som normale ekteskapelige konflikter. ${ }^{53}$ Staten mente det ikke var uvanlig at kvinner blir presset til samleie.

I TOSLO-2015-201075 (Oslo tingrett) viser tingretten til en avgjørelse der UNE gir uttrykk for at gjentatt vold, trusler og seksuelle overgrep ikke kunne kvalifiseres som mishandling etter utlendingsloven. UNEs beslutning i denne saken er ifølge tingretten ikke i samsvar med lovens forarbeider, og basert på feil rettsanvendelse. ${ }^{54}$

Både LB-2016-116118-2 (Borgarting lagmannsrett), TOSLO-2015-201075 (Oslo tingrett) og TOSLO-2006-15372 (Oslo tingrett) gir uttrykk for at UNE i enkelte avgjørelser har lagt til grunn en for høy terskel for hva som omfattes av mishandlingsbegrepet i utlendingsloven. I begge tingsrettsdommene mener domstolen at UNE har tatt feil i sin vurdering av mishandlingskravet. Ovennevnte taler i retning av at praktiseringen av unntaksbestemmelsen er for streng i forhold til lovgivers ønske.

\section{Terskelen for mishandling i forvaltningspraksis}

Jeg har lest gjennom alle offentliggjorte avgjørelser fra UNE. Ved søk i UNEs databaser finner jeg 41 saker etter 2010 under sakstype «familie» og stikkord «mishandling». ${ }^{55}$ Noen av avgjørelsene er lagt ut flere ganger under ulike referansenummer. Det er lagt ut 17 saker fra de siste fem år. ${ }^{56}$ Det kan ikke føres statistikk fra praksisbasen ettersom UNE kun har lagt ut sammendrag av et utvalg avgjørelser. ${ }^{57}$ I UNE er det kun stornemndavgjørelser som er presedensdannende. ${ }^{58}$

Samtlige saker i mitt søk omhandler oppholdstillatelse, de fleste søknad om oppholdstillatelse på selvstendig grunnlag på grunn av mishandling. Søknad om oppholdstillatelse er ikke tatt til

\footnotetext{
${ }^{53}$ Se fotnote 50 .

54 TOSLO-2015-201075 (Oslo tingrett).

${ }^{55}$ Søk utført 14.10.2019. I januar 2020 endret UNE databasen, og det er dermed ikke mulig å gjenfinne vedtakene fra før 2015 i praksisbasen. Der jeg ikke finner nye henvisninger, viser jeg til basen slik den var før januar 2020.

56 Søk utført 15.02.2020.

${ }^{57} \mathrm{UNE}$, «UNE sin praksisbase» - https://www.une.no/kildesamling/praksisbase-landingsside/ (sist besøkt 15.02.2020).

${ }^{58}$ Se fotnote 57.
} 
følge i flertallet av de avgjørelser som er lagt ut. Der søknad er tatt til følge, er det ikke alltid på bakgrunn av mishandling. UNE nevner også andre avgjørende momenter. For eksempel «de sosiale, religiøse og kulturelle forholdene i Pakistan». ${ }^{59}$ Det forekommer også at søknad om opphold etter utlendingslovens $\S 53$ første ledd bokstav b ikke tas til følge på grunn av at vilkår om oppholdstillatelse etter utlendingsloven $\S \S 40$ eller 41 ikke er oppfylt. ${ }^{60}$

I min analyse av forvaltningspraksis vil jeg gå nærmere inn på to tilfeldig valgte avgjørelser fra UNE for å eksemplifisere noen trekk som jeg tolker går igjen. Jeg mener de er illustrerende for problemstillingen, og at de ikke skiller seg vesentlig fra øvrige avgjørelser som er offentliggjort av UNE. Nemndleder behandlet begge sakene etter forberedelse fra sekretariatet da det ikke forelå vesentlige tvilsspørsmål, jf. utlendingsloven $§ 78$ tredje ledd.

Forvaltningspraksis knyttet til utlendingsloven $§ 53$ første ledd bokstav b viser at avslag på søknad om selvstendig oppholdstillatelse ofte begrunnes med at forarbeidenes krav til redusert livskvalitet ikke er oppfylt. ${ }^{61}$ Det kan stilles spørsmål ved hvorfor utlendingslovens forarbeider krever redusert livskvalitet og skade av psykisk eller fysisk art når forarbeidene til straffeloven ikke gjør det.

Et gjennomgående moment i sakene er videre at søker som oftest blir trodd i sine anførsler, men UNE kategoriserer hendelsene som noe mindre alvorlige enn mishandling, for eksempel i sak N122626214 fra 2011. ${ }^{62}$ Klagen på avslag om søknad om oppholdstillatelse på selvstendig grunnlag ble ikke tatt til følge for kvinnen fra Tyrkia. Hun beskrev å være utsatt for et voldsomt press, psykisk vold, nektelse av penger og nektelse av bevegelsesfrihet fra ektefelle og hans familie. Hun ble også nektet å snakke med egen familie. Kvinnen beskrev selv en følelse av å være behandlet som «stuepike». Hun hadde ifølge forklaringen prøvd å ta

\footnotetext{
${ }^{59}$ Referanse: N128364214, 2011 -

http://praksis.une.no/CES5/default.aspx?\&sk=NyLov\&ccr=ct104\&k=cchd\&docid=10241\&mir=-

$1 \& q=\% 40$ sysuri+\%40Sakstype $\% 3 \mathrm{~d} \% 3 \mathrm{~d} \% 22$ Familie $\% 22+\% 40$ Stikkord $\% 3 \mathrm{~d} \% 22$ mishandling $\% 22+\% 40$ sysfilety pe\%3C\%3Espuserprofile+(NOT+\%40sysspiscontainer)\&wld=True (sist bes $\varnothing \mathrm{kt} \mathrm{17.4.2019).}$

${ }^{60}$ Referanse: N1861670703, 2017 - https://www.une.no/kildesamling/praksisbaselandingsside/2017/august/n1861670703/ (sist besøkt 15.2.2020).

${ }^{61}$ Se bl.a. N1838300214, 2017 - https://www.une.no/kildesamling/praksisbaselandingsside/2017/juni/n1838300214/ (sist besøkt 15.2.2020).

${ }^{62}$ Referanse: N122626214, $2011-$

http://praksis.une.no/CES5/default.aspx?\&sk=NyLov\&ccr=ct104\&k=cchd\&docid=10776\&mir=$1 \& q=\% 40$ sysuri+\%40Sakstype $\% 3 \mathrm{~d} \% 3 \mathrm{~d} \% 22$ Familie $\% 22+\% 40$ Stikkord $\% 3 \mathrm{~d} \% 22$ mishandling $\% 22+\% 40$ sysfilety pe $\% 3 \mathrm{C} \% 3$ Espuserprofile+(NOT+\%40sysspiscontainer)\&wld=True (sist bes $\varnothing \mathrm{kt} \mathrm{17.4.2019).}$
} 
sitt eget liv som følge av behandlingen. Hendelsene ble ikke ansett som psykisk mishandling etter UNEs mening.

Kvinnen anførte videre å ha blitt dyttet, klapset til og slått med flat hånd slik at hun fikk blåmerke. Fysisk vold hadde visstnok skjedd ved 2-3 anledninger. Krisesenteret forteller at kvinnen var «preget av volden og overgrepene hun hadde blitt utsatt for, blant annet hadde hun fysiske smerter og angstanfall i form av pusteproblemer». UNE mente den beskrevne fysiske volden ikke var av slik art og slikt omfang at den i seg selv kunne anses som mishandling. UNE påpekte at det er uakseptabelt at man blir slått, men det dreide «seg her om lite alvorlige og enkeltstående episoder».

I denne avgjørelsen ser det ut til at UNE har vurdert de ulike episodene med fysisk vold og psykisk vold hver for seg, og ikke hvordan hendelsene i sin helhet kan påvirke kvinnen. I den tidligere nevnte høyesterettsdom ble det gitt uttrykk for at truslene som fremsettes og den $\emptyset$ vrige voldsbruken må ses i sammenheng med hvor hardt de rammer den fornærmede. ${ }^{63}$ Lovgiver er som nevnt klar på at også psykisk vold omfattes av bestemmelsen. Et sentralt formål med mishandlingsbestemmelsen i straffeloven var å straffe de psykiske krenkelsene som ofte kjennetegner vold i nære relasjoner. ${ }^{64}$ Forskning viser at psykisk vold er minst like skadelig som fysisk vold. ${ }^{65}$ Kvinnevoldsutvalget har også uttalt at hver voldsepisode ikke kan ses som en isolert hendelse. ${ }^{66}$ De viser til at forskere på området mener frykten for hva som kan eller vil skje, blir en del av mannens maktutøvelse. Frykten blir da også en sentral del av kvinnens virkelighet. ${ }^{67}$ Det kan argumenteres for at enkeltstående slag sammen med truende adferd fører til at kvinnen lever i frykt for at fysisk vold utøves igjen.

Det kan også se ut som om det er lettere for flere av kvinnene å få oppholdstillatelse dersom de er utsatt for fysisk vold. I sak N1838020214 fra 2017 mente UNE under tvil at det var grunn til å anta at en kvinne under samlivet med ektefellen var blitt mishandlet $\mathrm{i}$ utlendingslovens forstand. ${ }^{68}$ Kvinnen fra Thailand anførte at ektemannen jevnlig, mellom 2011 og 2016, fysisk mishandlet henne. Hun ble utsatt for seksuell tvang og vold, herunder en

\footnotetext{
${ }^{63}$ HR-2019-621-A (avsnitt 21).

${ }^{64}$ Ot.prp. nr. 113 (2004-2005) s. 36-37 og mindretallet i HR-2019-621-A (avsnitt 31).

${ }^{65}$ Se bl.a. Roland Maiuro (red.), Perspectives on verbal and psychological abuse, New York 2015.

${ }^{66}$ NOU 2003: 31 Retten til et liv uten vold, s. 49.

${ }^{67}$ Se fotnote 66.

68 Referanse: N1838020214, 2017 - https://www.une.no/kildesamling/praksisbaselandingsside/2017/oktober/n1838020214/ (sist besøkt 17.4.2019).
} 
voldsepisode der hun besvimte som følge av slag fra ektefellen. I tillegg ble hun utsatt for psykisk mishandling, som drapstrusler, nedsettende språk og kontrollerende adferd.

Mishandlingskravet var oppfylt fordi de anførte forhold hadde funnet sted over en lengre tidsperiode, i tillegg til at klagerens barn hadde vært vitne til og utsatt for volden.

Det kan videre problematiseres hvor lenge en kvinne skal leve med volden for at kravet til mishandling etter utlendingsloven er oppfylt. I HR-2019-621-A var krenkelser utført over en periode på fire måneder på grensen til å nå terskelen for mishandling etter straffeloven. Ved vurdering av oppholdstillatelse for kvinnen fra Tyrkia la UNE blant annet vekt på at hun bare hadde levd $i$ et vanskelig ekteskap i et par måneder. Videre mente UNE at jevnlig vold mellom 2011 og 2016 mot kvinnen fra Thailand var på grensen til å heller ikke være mishandling.

Det er etter dette grunn til å stille spørsmål ved om lagmannsrettens uttalelser om at terskelen for å konstatere mishandling etter utlendingsloven skal være lavere enn for mishandlingsbegrepet etter straffelovens bestemmelse om vold i nære relasjoner, samsvarer med UNEs høye terskel for hva som omfattes av mishandlingsbegrepet i utlendingsloven. Jeg mener de offentliggjorte avgjørelser fra UNE viser at mishandlingsbestemmelsen i praksis ofte tolkes strengere enn det rettstilstanden tilsier at den skal.

Som støtte for et slikt syn kan det vises til at flere advokater, rådgivere og ansatte på krisesenter anbefaler kvinnene heller å søke opphold på annet grunnlag. ${ }^{69}$ Bakgrunn for anbefalingen er at terskelen for å konstatere mishandling anses som høy, og det vil være større sannsynlighet for å få opphold på annet grunnlag.

Videre viser tall fra Barne-, ungdoms- og familiedirektoratet (heretter Bufdir) at flere beboere på norske krisesenter oppga manglende permanent oppholdstillatelse som årsak for retur til voldsutøver. ${ }^{70}$ I de tilfeller hvor beboeren oppga at voldsutøver var ektefelle eller samboer, endte 22 prosent av oppholdene med å flytte tilbake til voldsutøver. ${ }^{71}$ Tallene kan tyde på at

\footnotetext{
${ }^{69}$ Likestillings- og diskrimineringsombudet, «Høringssvar - Endringer i utlendingsloven og utlendingsforskriften - hevet botidskrav for permanent oppholdstillatelse mv. - endringer i statsborgerloven», 2015 (s. 6) (se fotnote 14 for URL-adresse).

${ }^{70}$ Bufdir statistikk, «Hvor dro beboerne etter oppholdet?», 2018 https://www.bufdir.no/Statistikk_og_analyse/Vold_og_overgrep_tall_og_statistikk/Krisesentertilbudet_i_norske _kommuner/Om_beboerne/\#heading46771 (sist besøkt 14.10.2019).

${ }^{71}$ Se fotnote 68 .
} 
noen kvinner som utsettes for mishandling, fortsetter samlivet i frykt for at mishandlingen ikke er alvorlig nok. Høringsuttalelser fra JURK støtter opp under synet. ${ }^{72}$

\section{Internasjonal kritikk}

Norge er forpliktet til å føre en politikk som tar sikte på å avskaffe alle former for kvinnediskriminering, jf. Convention on the Elimination of All Forms of Discrimination against Women, 18 December 1979 (heretter FNs kvinnekonvensjon) artikkel 2. FNs kvinnekonvensjon nevner ikke en særskilt plikt til å bekjempe vold mot kvinner. Plikten kan likevel tolkes ut fra hensyn og formål bak konvensjonen som nevnt i fortalen, samt uttalelser fra The Committee on the Elimination of Discrimination against Women (heretter komitéen). For eksempel har komitéen uttalt at kjønnsbasert vold er inkludert i definisjonen av kvinnediskriminering etter konvensjonen artikkel $1 .^{73}$

FNs kvinnediskrimineringskomité er opprettet med hjemmel i FNs kvinnekonvensjon artikkel 17 nr. 1, og vurderer jevnlig om Norge følger sine plikter som konvensjonspart. Komitéen har ved flere anledninger uttrykt bekymring for situasjonen til minoritetskvinner i Norge. ${ }^{74}$ Den peker særskilt på at treårskravet kan tvinge voldsutsatte minoritetskvinner til å holde ut $\mathrm{i}$ voldspregede relasjoner. ${ }^{75}$ Komitéen anbefaler derfor Norge å evaluere utlendingsrettens regelverk og retningslinjer, for å sikre at disse ikke får uforholdsmessige konsekvenser for minoritetskvinner. ${ }^{76}$ Uttalelser fra FNs kvinnediskrimineringskomité er ikke folkerettslig bindende. ${ }^{77}$ Selv om den rettskildemessige verdien av slike «concluding observations» er begrenset, anses uttalelsene likevel å være av betydning. ${ }^{78}$

\footnotetext{
72 JURK, «Høring - endringer i utlendingsloven - fortsatt opphold ved mishandling i samlivsforholdet», 2017 (s. 2) - https://www.regjeringen.no/no/dokumenter/horing----endringer-i-utlendingsloven-utvidelse-avmishandlingsbestemmelsen/id2553350/?uid=2cb9d965-8e03-48a7-a3a2-c9ea479141c7 (sist besøkt 5.4.2019). ${ }^{73}$ FNs kvinnediskrimineringskomité, «General recommendations adopted by the committee on the elimination of discrimination against women No. 19: Violence against women», $1992-$ https://tbinternet.ohchr.org/Treaties/CEDAW/Shared\%20Documents/1_Global/INT_CEDAW_GEC_3731_E.pd f (sist besøkt 29.4.2019).

${ }^{74}$ FNs kvinnediskrimineringskomité, «Concluding observations of the Committee on the Elimination of Discrimination against Women», 2012 (s. 9) https://tbinternet.ohchr.org/_layouts/treatybodyexternal/Download.aspx?symbolno=CEDAW\%2fC\%2fNOR\%2f CO\%2f8\&Lang=en (sist besøkt 29.04.19) og «Concluding observations on the ninth periodic report of Norway», 2017 (s. 10-11) https://tbinternet.ohchr.org/_layouts/treatybodyexternal/Download.aspx?symbolno=CEDAW\%2fC\%2fNOR\%2f CO\%2f9\&Lang=en (sist besøkt 29.4.2019).

${ }^{75}$ Se fotnote 74.

${ }^{76}$ FNs kvinnediskrimineringskomité, «Concluding observations on the ninth periodic report of Norway», 2017 (s. 11) (se fotnote 74 for URL-adresse).

77 Thom Arne Hellerslia, «Uttalelser fra FN-komiteene - en strukturell analyse», Jussens Venner, 2018 s. $71-$ 111 (s. 74).

${ }^{78}$ Thom Arne Hellerslia (s. 80).
} 


\section{Konklusjon}

Artikkelen viser at treårskravet medfører en svekkelse av voldsutsatte minoritetskvinners rettssikkerhet i Norge. Utlendingsloven $\S 53$ første ledd bokstav b vil i noen grad begrense de negative konsekvensene av treårskravet ved at bestemmelsen åpner for selvstendig oppholdstillatelse ved mishandling.

Samtidig viser artikkelen at unntaksbestemmelsen tolkes strengt, og at det i realiteten foreligger en høy terskel for å sannsynliggjøre mishandling. Det kan stilles spørsmål ved nødvendigheten av å tolke mishandlingskravet så strengt, da bestemmelsen allerede har et sannsynlighetskrav. Bør det ikke være tilstrekkelig at voldsbruken er sannsynliggjort?

Slik regelverket er utformet og praktisert i dag, evner ikke unntaksbestemmelsen i tilstrekkelig grad å begrense de negative konsekvensene av treårskravet. Det kan herunder trekkes frem at forarbeidenes krav til redusert livskvalitet og skaderesultat på offerets legeme eller sjel åpner for en krevende vurdering som i stor grad er basert på den enkelte saksbehandlers skjønn. Kravene samsvarer heller ikke med vurderingen av mishandling etter straffeloven. Det kan derfor være nødvendig at lovgiver ser på hvilke krav som stilles til mishandling, både i forarbeider til utlendingsloven $\S 53$ første ledd bokstav b og tilhørende praksis.

Takk til Mona Martnes for god veiledning i forbindelse med masteroppgave og artikkel, og anonym fagfelle for gode kommentarer. 